\title{
Perbandingan Profil Hematologi dan Trombopoietin sebagai Petanda Sepsis Neonatorum Awitan Dini
}

\author{
Rocky Wilar, Silfy Welly, Nurhayati Masloman, Suryadi Tatura \\ Bagian Ilmu Kesehatan Anak Fakultas Kedokteran Universitas Sam Ratulangi/RSUP Prof.Dr.R.D.Kandou, Manado
}

Latar belakang. Sepsis neonatorum memiliki gejala klinis yang tidak spesifik dan diagnosis dengan pemeriksaan kultur memerlukan waktu yang lama. Telah dilaporkan derajat sepsis bertambah seiring peningkatan kadar trombopoietin (TPO) sehingga TPO dapat dijadikan salah satu petanda derajat sepsis.

Tujuan. Membandingkan profil hematologi dengan TPO sebagai petanda sepsis neonatorum awitan dini (SNAD).

Metode. Studi potong lintang, dilakukan di Sub Bagian Neonatologi Bagian Ilmu Kesehatan Anak RSUP.Prof.Dr.R.D.Kandou, bulan November 2012 sampai April 2014. Didapatkan 103 neonatus tersangka SNAD. Diperbandingkan kadar profil hematologi (jumlah leukosit, jumlah trombosit dan IT rasio) dengan TPO.

Hasil. Hasil uji diagnostik TPO dengan cut-offpoint $259 \mathrm{pg} / \mathrm{mL}$ pada SNAD diperoleh nilai sensitivitas 76,8\% dan spesifisitas 24,4\%; jumlah trombosit (T) sensitivitas 42,9\% dan spesifisitas 87,2\%; jumlah leukosit (L) sensitivitas 30,4\% dan spesifisitas $87,3 \%$; ITrasio (IT) sensitivitas $67,3 \%$ dan spesifisitas 50\%; L+T diperoleh sensitivitas 58,9\% dan spesifisitas 74,5\%; L+IT sensitivitas 73,2\% dan spesifisitas 46,8\%; T+IT sensitivitas 78,6\% dan spesifisitas 44,7\% sedangkan L+T+IT sensitivitas $83,9 \%$ dan spesifisitas 34\%.

Kesimpulan. Sensitivitas dan spesifisitas TPO tidak lebih tinggi dibandingkan dengan profil hematologi sebagai petanda diagnosis SNAD. Sari Pediatri 2017;18(6):481-6

Kata kunci: Jumlah trombosit, jumlah leukosit, IT-rasio, trombopoietin, tersangka sepsis, sepsis neonatorum awitan dini

\section{A Comparison of Hematology Profile and Thrombopoietin for Diagnosing Early-Onset Neonatal Sepsis}

\begin{abstract}
Rocky Wilar, Silfy Welly, Nurhayati Masloman, Suryadi Tatura
Background. Neonatal sepsis has not spesific clinical symptoms and diagnosing with blood culture takes a long time. It had been reported the severity of sepsis increased with increasing levels of thrombopoietin (TPO), that TPO can be used as a marker of the degree of sepsis.

Objective. To compare the sensitivity and specificity of hematological profile and TPO for diagnosing early onset neonatal sepsis (EONS).

Method. A cross-sectional study, was conducted in the Neonatology division Prof.Dr.R.D.Kandou general hospital from November 2012 to April 2014. There were 103 newborns with suspected EONS who fulfilled the inclusion criteria. Hematology profile (leukocyte-count, platelet-count and IT-ratio) and TPO measurements were performed.

Results. TPO with the cut-off point of $259 \mathrm{pg} / \mathrm{mL}$ in EONS, obtained sensitivity $76.8 \%$ and specificity $24.4 \%$. Sensitivity of Leukocytes (L) $30.4 \%$ and specificity $87.3 \%$; sensitivity of platelet-count (T) $42.9 \%$ and specificity $87.2 \%$; sensitivity of IT-ratio (IT) $67.3 \%$ and specificity $50 \%$; L+T obtained sensitivity of $58.9 \%$ and specificity $74.5 \%$; L+IT obtained sensitivity $73.2 \%$ and specificity 46.8\%; T+IT obtained sensitivity $78.6 \%$ and specificity $44.7 \%$, while L+T+IT obtained sensitivity $83.9 \%$ and specificity $34 \%$.

Conclusion. TPO has not higher sensitivity and spesificity than the hematological profile for early diagnosis of EONS. Sari Pediatri 2017;18(6):481-6
\end{abstract}

Keywords: platelet count, leukocyte count, IT-ratio, thrombopoietin, EONS

Alamat korespondensi: Dr. Rocky Wilar, SpA(K). Bagian Ilmu Kesehatan Anak Fakultas Kedokteran Universitas Sam Ratulangi / RSUP Prof.

Dr.R.D.Kandou, Manado. E-mail: rocky_wilar@yahoo.com. 
S epsis neonatorum merupakan penyebab utama morbiditas dan mortalitas pada neonatus di negara berkembang. Penyakit ini sering tidak terdeteksi dan menyebabkan kematian dalam waktu singkat, tetapi dapat diobati jika didiagnosis lebih dini. ${ }^{1,2}$

Di negara berkembang, insiden sepsis neonatorum 170 per 1000 kelahiran hidup (diagnosis secara klinis) dan 5,5\% per 1000 kelahiran hidup (konfirmasi dengan kultur darah). ${ }^{3}$ Di Divisi Perinatologi Ilmu Kesehatan Anak-Rumah Sakit Cipto Mangunkusumo (IKARSCM) dalam periode Desember 2006 - Juli 2007, 334 neonatus tersangka sepsis didapatkan hasil biakan darah positif 148 (44,3\%) kasus. ${ }^{4}$ Data dari Sub Bagian Neonatologi RSUP. Prof. Dr. R.D. Kandou Manado periode Januari - Agustus 2009 didapatkan 56 kasus sepsis neonatorum dengan 36 kultur darah positif. ${ }^{5}$

Sepsis neonatorum adalah sindrom klinis yang timbul akibat invasi mikroorganisme ke dalam aliran darah yang timbul pada bulan pertama kehidupan. Pada sepsis neonatorum terdapat infeksi aliran darah yang bersifat invasif dan ditandai dengan ditemukannya bakteri, virus, jamur, protozoa atau riketsia dalam cairan tubuh seperti darah, cairan sumsum tulang atau air kemih. ${ }^{6}$ Dari awitan gejala, sepsis neonatorum dibedakan menjadi dua jenis yaitu sepsis neonatorum awitan dini (SNAD) terjadi dalam 72 jam pertama kehidupan dan sepsis neonatorum awitan lanjut (SNAL) terjadi setelah 72 jam pertama kehidupan. ${ }^{7}$

Diagnosis klinis sepsis neonatorum mempunyai masalah tersendiri. "Suspek sepsis / tersangka sepsis" adalah salah satu diagnosis yang paling sering dibuat di neonatal intensive care unit (NICU). Akan tetapi, gejala sepsis tidak spesifik, dan gejala inflamasi dari sumber noninfeksi menyerupai sepsis neonatorum. ${ }^{8}$ Pembuktian infeksi dengan biakan darah sering tidak menunjukkan hasil yang memuaskan dan memerlukan waktu yang lama. ${ }^{10}$ Berbagai usaha telah dilakukan untuk mendiagnosis dini sepsis neonatorum antara lain berdasarkan pemeriksaan profil hematologi dan TPO. ${ }^{2,9,11-16}$

Pada neonatus, produksi trombosit diatur oleh sitokin hematopoetik salah satunya yaitu trombopoietin (TPO) yang akan menstimulasi diferensiasi megakariosit menjadi trombosit matur. ${ }^{12}$ Penelitian sebelumnya melaporkan peningkatan konsentrasi TPO plasma meningkat pada neonatus dan anak dengan sepsis ${ }^{13,14}$
Karena identifikasi kuman yang sulit serta gambaran klinis yang tidak spesifik sehingga diagnosis sulit ditegakkan maka dipandang perlu untuk meneliti penanda yang dapat digunakan untuk mendiagnosis $\mathrm{SNAD}$ pada bayi tersangka sepsis.

\section{Metode}

Studi potong lintang dilakukan di ruang rawat Sub Bagian Neonatologi Bagian IKA RSUP Prof. Dr. R. D. Kandou Manado pada November 2012 sampai April 2014. Subjek penelitian adalah semua neonatus yang memenuhi kriteria inklusi. Kami menggunakan metode consecutive sampling. Subjek penelitian kemudian dilakukan pemeriksaan pemeriksaan fisik dan laboratorium (profil hematologi, IT rasio, kultur darah dan TPO)

Kriteria inklusi adalah neonatus cukup bulan tersangka sepsis neonatorum awitan dini (SNAD), sesuai masa kehamilan, lahir secara pervaginam atau sectio caesarea. Kriteria eksklusi apabila didapatkan kelainan bawaan, gemeli, prematur, mengalami asfiksia neonatorum. Tersangka SNAD ditegakkan berdasarkan adanya gejala klinis, faktor risiko sepsis dan pemeriksaan laboratorium. Penelitian ini telah disetujui Komite Etik FK UNRAT.

Seorang bayi tersangka sepsis bila memiliki dua kriteria mayor atau satu kriteria mayor ditambah dua atau lebih kriteria minor. Faktor risiko sepsis meliputi faktor risiko mayor yaitu ketuban pecah dini $(\mathrm{KPD})>18$ jam, ibu demam intrapartum $\left(>38^{\circ} \mathrm{C}\right)$, korioamnionitis, ketuban berbau, denyut jantung janin $>160 x /$ menit. Faktor risiko minor terdiri dari KPD > $12 \mathrm{jam}$, ibu demam intrapartum $\left(>37,5^{\circ} \mathrm{C}\right)$, skor Apgar rendah (menit 1 skor $<5$ dan menit 5 skor $<7$ ), berat badan lahir sangat rendah (<1500 gram), keputihan yang tidak diobati, dan ibu dicurigai mengalami infeksi saluran kemih. ${ }^{1}$

Bayi tersangka SNAD bila memiliki 4 atau lebih gejala klinis dan adanya 2 atau lebih kelainan profil hematologi (dengan atau tanpa biakan darah positif). Gejala klinis neonatal tersangka sepsis seperti letargi, refleks hisap menurun, merintih, iritabel, kejang, bradikardi, apneu, takipneu, saturasi oksigen diukur dengan pulse oxymeter $<85 \%$, pucat, penurunan perfusi, hipotermi, hipertermi, hipotoni, muntah, diare, ileus, kembung, feeding intolerance, waktu pengosongan lambung memanjang, anemia, icterus, 
petekie dan purupura. Kelainan profil hematologi seperti IT rasio $\geq 0,2$, leukopenia $\left(<5000 \mathrm{sel} / \mathrm{mm}^{3}\right)$, leukositosis $\left(>25.000 \mathrm{sel} / \mathrm{mm}^{3}\right)$ atau trombositopenia $\left(<150.000 \mathrm{sel} / \mathrm{mm}^{3}\right){ }^{1}$

Bayi dilakukan septic work-up yaitu pemeriksaan profil hematologi (hitung leukosit, hitung trombosit, IT rasio), TPO dan kultur darah, setelah mendapat informed consent dari orang tua penderita. Data diolah dengan statistical product and services solutions (SPSS) versi 21. Analisis deskriptif untuk menggambarkan karakteristik dari data, analisis ROC untuk menilai cut off point dari TPO, Chi-square untuk menguji nilai diagnostik dari TPO dan profil hematologi dengan menghitung sensitivitas, spesifisitas, nilai prediksi positif (NDP) dan nilai prediksi negatif (NDN), Uji Z dilakukan untuk menguji perbandingan sensitivitas, spesifisitas, NDP dan NDN dari TPO dan profil hematologi.

\section{Hasil}

Didapatkan 103 bayi yang lahir dengan tersangka sepsis yang memenuhi kriteria inklusi. Angka kejadian SNAD terbanyak pada neonatus lelaki 39 (69,9\%) dibandingkan neonatus perempuan 17 (30,4\%) seperti tertera pada Tabel 1 . Sedangkan distribusi karakteristik jumlah trombosit, jumlah leukosit, rasio IT dan TPO tertera pada Tabel 2.

Berdasarkan analisis receiver operating characteristic (ROC) diperoleh cut-off point TPO $259 \mathrm{pg} / \mathrm{mL}$ (Gambar 2). Berdasarkan cut-off point ini diperoleh

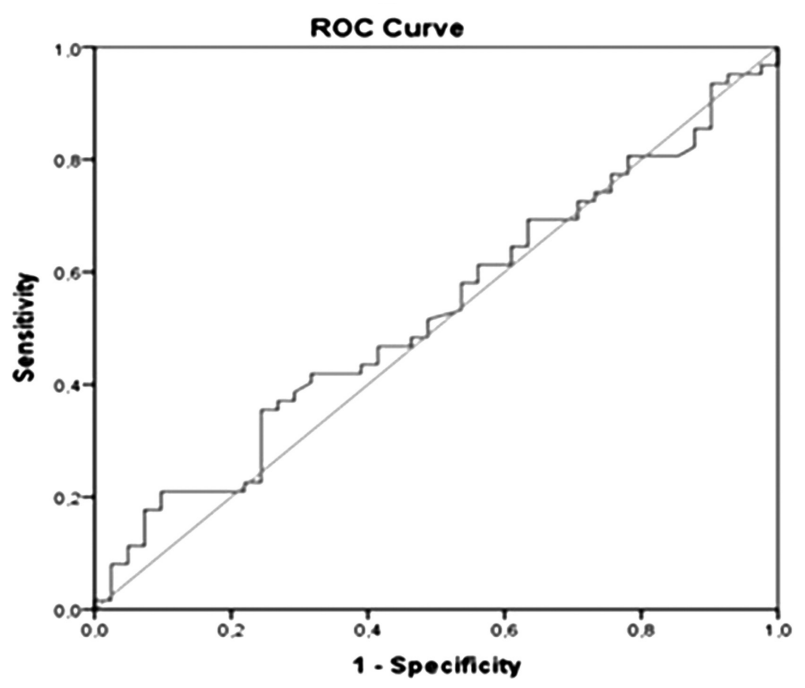

Gambar 2. Kurva ROC trombopoietin pada sepsis neonatorum awitan dini

Tabel 1. Karakteristik subyek penelitian

\begin{tabular}{lccc}
\hline Jenis kelamin & SNAD & Bukan SNAD & Total \\
\hline Laki-laki, $\mathrm{n}(\%)$ & $39(69,6)$ & $24(51,1)$ & $63(61,2)$ \\
Perempuan, $\mathrm{n}(\%)$ & $17(30,4)$ & $23(48,9)$ & $40(38,8)$ \\
\hline Jumlah & $56(100)$ & $47(100)$ & $103(100)$ \\
\hline
\end{tabular}

Tabel 2. Distribusi karakteristik jumlah trombosit, jumlah leukosit, rasio IT dan TPO

\begin{tabular}{llcccc}
\hline Diagnosis & Trombosit & $\begin{array}{c}\text { Leukosit } \\
(\mathrm{sel} / \mathrm{mm} 3)\end{array}$ & rasio IT & $\begin{array}{c}\text { TPO } \\
(\mathrm{pg} / \mathrm{mL})\end{array}$ \\
\hline \multirow{2}{*}{ SNAD } & Terendah & 4.000 & 4.500 & 0,04 & 122,50 \\
& Tertinggi & 352.000 & 46.500 & 0,57 & $1.726,10$ \\
& Rerata & 172.582 & 20.153 & 0,27 & 561,98 \\
& SB & 81.956 & 9.585 & 0,15 & 401,22 \\
& Median & 172.000 & 18.400 & 0,25 & 409,20 \\
& IK95\% & $150.426-194.738$ & $17.562-22.744$ & $0,23-0,31$ & $453,52-670,45$ \\
\hline \multirow{2}{*}{ Bukan SNAD } & Terendah & 40.000 & 6.300 & 0,01 & 131,90 \\
& Tertinggi & 369.000 & 30.700 & 0,58 & $1.704,50$ \\
& Rerata & 215.825 & 18.405 & 0,20 & 494,17 \\
& SB & 66.083 & 5.743 & 0,10 & 319,84 \\
& Median & 213.000 & 19.400 & 0,19 & 404,90 \\
& IK95\% & $194.691-236.959$ & $16.568-20.242$ & $0,17-0,23$ & $391,88-596,46$ \\
\hline
\end{tabular}


Rocky Wilar dkk: Perbandingan profil hematologi dan trombopoietin sebagai petanda SNAD

Tabel 3. Nilai sensitivitas, spesifisitas, NDP dan NDN TPO, trombosit (T), leukosit (L), IT rasio (IT) pada SNAD

\begin{tabular}{lccccccccc}
\hline Variabel & Sensitivitas & Uji Z & Spesifisitas & Uji Z & NDP & Uji Z & NDN & Uji Z & OR \\
\hline TPO & $76,8 \%$ & & $23,4 \%$ & & $54,4 \%$ & & $45,8 \%$ & & $1,0(0,4-2,5)$ \\
Leukosit (L) & $30,4 \%$ & $\mathrm{p}<0,001$ & $87,3 \%$ & $\mathrm{p}<0,001$ & $73,9 \%$ & $\mathrm{p}=0,047$ & $51,3 \%$ & $\mathrm{p}=0,318$ & $2,98(1,06-8,3)$ \\
Trombosit (T) & $42,9 \%$ & $\mathrm{p}<0,001$ & $87,2 \%$ & $\mathrm{p}=0,005$ & $80,0 \%$ & $\mathrm{p}=0,007$ & $56,2 \%$ & $\mathrm{p}=0,188$ & $5,1(1,9-14,0)$ \\
IT rasio (IT) & $67,3 \%$ & $\mathrm{p}=0,132$ & $50,0 \%$ & $\mathrm{p}<0,001$ & $64,9 \%$ & $\mathrm{p}=0,110$ & $52,6 \%$ & $\mathrm{p}=0,301$ & $2,1(0,9-4,7)$ \\
L + T & $58,9 \%$ & $\mathrm{p}=0,021$ & $74,5 \%$ & $\mathrm{p}<0,001$ & $73,3 \%$ & $\mathrm{p}=0,019$ & $60,3 \%$ & $\mathrm{p}=0,114$ & $4,2(1,8-9,7)$ \\
L + IT & $73,2 \%$ & $\mathrm{p}=0,330$ & $46,8 \%$ & $\mathrm{p}=0,009$ & $62,1 \%$ & $\mathrm{p}=0,175$ & $59,5 \%$ & $\mathrm{p}=0,147$ & $2,4(1,1-5,5)$ \\
T + IT & $78,6 \%$ & $\mathrm{p}=0,409$ & $44,7 \%$ & $\mathrm{p}=0,015$ & $62,9 \%$ & $\mathrm{p}=0,147$ & $63,6 \%$ & $\mathrm{p}=0,091$ & $2,96(1,25-6,9)$ \\
L + T + IT & $83,9 \%$ & $\mathrm{p}=0,172$ & $34,0 \%$ & $\mathrm{p}=0,128$ & $60,3 \%$ & $\mathrm{p}=0,227$ & $64,0 \%$ & $\mathrm{p}=0,100$ & $2,69(1,06-6,8)$ \\
\hline
\end{tabular}

hasil uji diagnostik SNAD terhadap TPO, yaitu nilai sensitivitas TPO 76,8\% dan spesifisitas $23,4 \%$.

Nilai sensitifitas, spesifisitas, NDP dan NDN dari variabel-variabel TPO dan profil hematologi (jumlah leukosit, jumlah trombosit dan rasio IT) serta hasil perbandingan uji $\mathrm{Z}$ variabel TPO terhadap profil hematologi tertera pada Tabel 3.

\section{Pembahasan}

Perbandingan bayi yang menderita sepsis didapatkan pada bayi lelaki lebih banyak 2,1 kali dibandingkan bayi perempuan. Menurut kepustakaan, sepsis lebih sering terjadi pada bayi lelaki daripada perempuan. Hasil penelitian kami serupa dengan penelitian sebelumnya. ${ }^{15-17}$ Rerata jumlah leukosit adalah 20.153 $\mathrm{sel} / \mathrm{mm}^{3}$. Penelitian kami mendapatkan $69,6 \%$ neonatus dengan SNAD memiliki nilai leukosit yang normal. Penelitian terdahulu menunjukkan rerata jumlah leukosit pada sepsis neonatorum adalah 19.100 $\mathrm{sel} / \mathrm{mm}^{3}{ }^{36}$ Peneliti lain melaporkan bahwa $60 \%$ dari subyek dengan kultur darah positif memiliki nilai leukosit yang normal $(5.000 \mathrm{sel} / \mathrm{mm} 3-19.999 \mathrm{sel} /$ $\left.\mathrm{mm}^{3}\right){ }^{18}$

Kami mendapatkan sensitivitas jumlah leukosit $30,4 \%$ dengan nilai spesifisitas $87,3 \%$, NDP 73,9\%, dan NDN 51,3\%, sedangkan penelitian sebelumnya melaporkan nilai sensitivitas jumlah leukosit 56\%, spesifisitas 91\%, NDP 85\% dan NDN 70\%. Hal tersebut mungkin dikarenakan pada penelitian sebelumnya mendefinisikan leukositosis bila jumlah leukosit $>20.000 \mathrm{sel} / \mathrm{mm}^{3}$, sedangkan pada penelitian kami definisi leukositosis yakni jumlah leukosit $>25.000 \mathrm{sel} / \mathrm{mm}^{3}$.

Leukosit PMN banyak ditemukan pada kasus dengan sepsis bakterialis. Pelepasan leukosit PMN dari sumsum tulang diinduksi oleh endotoksin, sitokin, komplemen serta granulocyte colony stimulating factor. Selain terjadi perlekatan leukosit dengan sel endotel, terjadi pula proses kemotaksis, fagositosis PMN untuk membunuh mikroorganisme. Pada neonatus mekanisme pertahanan innate terhadap bakteri yang terjadi secara dini adalah neutrofil atau PMN (leukosit polimorfonuklear). Terdapat tiga aspek dari fungsi PMN yang berperan penting dalam sepsis neonatal, yaitu neutropenia, penurunan deformabilitas dan keterlambatan apoptosis. Jumlah lekosit (leukopeni / leukositosis) memberikan panduan tentang beratnya proses penyakit. ${ }^{19-21}$

Penelitian kami mendapatkan peningkatan IT rasio pada 67,3\% neonatus dengan SNAD. Hal tersebut sesuai dengan penelitian sebelumnya pada pasien dengan sepsis neonatorum yang juga didapatkan peningkatan IT rasio. ${ }^{22}$ Sensitivitas IT rasio $67,3 \%$ dan spesifisitas $50,0 \%$ tidak berbeda jauh dengan penelitian terdahulu dengan nilai spesifisitas untuk IT rasio $>0,2$ adalah $54,6 \%$ dan spesifisitas $73,7 \% .{ }^{23}$ Adapun peneliti lain melaporkan sensitivitas IT rasio 93,75\% dan spesifisitas $94,44 \% .^{2}$ Perbedaan tersebut mungkin disebabkan kriteria inklusi pada penelitian sebelumnya adalah neonatus berusia 1-7 hari, sedangkan kriteria inklusi yang kami gunakan adalah neonatus baru lahir dengan pengambilan sampel darah segera setelah lahir.

Trombositopenia dengan SNAD dialami 80\% neonatus. Trombositopenia terjadi kurang dari 3\% pada bayi sehat. Sebaliknya, 10\%-60\% kasus sepsis neonatorum mengalami trombositopenia. ${ }^{23}$ Studi lain menyatakan bahwa 90\% kasus sepsis neonatorum mengalami trombositopenia. ${ }^{24}$ Kami mendapatkan sensitivitas trombosit $42,9 \%$ dan spesifisitas $87,2 \%$ dibandingkan dengan penelitian oleh Makkar $\mathrm{dkk}^{2}$ yang melaporkan nilai sensitivitas $81 \%$ dan spesifisitas 94\%. Hal tersebut dapat disebabkan pada penelitian 
sebelumnya dilakukan pada neonatus $<1$ minggu.

Trombositopenia pada sepsis neonatorum terjadi akibat penurunan produksi trombosit, peningkatan destruksi dan/atau sekuestrasi trombosit. Penyebab utama trombositopenia pada sepsis adalah destruksi trombosit. ${ }^{25}$ Pada kasus sepsis terjadi hemofagositosis di sumsum tulang, baik terhadap megakariosit maupun terhadap sel darah lainnya, oleh monosit, dan makrofag. ${ }^{26}$

Trombopoiesis atau pembentukan trombosit adalah sebuah proses kompleks. Trombopoietin adalah regulator megakariopoiesis dan trombopoiesis. ${ }^{14}$ Nilai normal TPO bayi aterm yang sehat bervariasi antara 3,7 - $356 \mathrm{pg} / \mathrm{mL} .{ }^{14,27}$ Selama infeksi sistemik, hati menghasilkan substansi multifungsional termasuk sitokin hematopoiesis, salah satunya adalah TPO. Kadar TPO dalam sirkulasi penderita sepsis neonatorum lebih tinggi daripada neonatus normal, yang menunjukkan bahwa peningkatan konsenstrasi TPO dikarenakan destruksi platelet dan dilepaskannya cadangan TPO dari organel platelet atau karena terhambatnya reseptor megakariosit dan trombosit dan penurunan uptake dan metabolisme TPO. ${ }^{28}$

Bayi dengan trombosit normal yang berpotensi terinfeksi dengan faktor risiko ibu, seperti demam intrapartum dan ketuban berbau memiliki kadar TPO intrauterin yang lebih tinggi. Hal tersebut menunjukkan bahwa inflamasi akut menyebabkan peningkatan signifikan pada mRNA TPO hepatik yang akhirnya meningkatkan produksi TPO hepatik. ${ }^{12,29}$

Median TPO neonatus dengan SNAD adalah $409,20 \mathrm{pg} / \mathrm{mL}$. Berbeda dengan penelitian terdahulu, median TPO pada sepsis neonatorum $1856 \mathrm{pg} / \mathrm{mL} .{ }^{14}$ Hal tersebut diduga karena populasi yang digunakan pada penelitian sebelumnya adalah neonatus berusia kurang dari 28 hari. Studi lain melaporkan peningkatan kadar TPO pada kasus sepsis neonatorum dengan median TPO $159 \mathrm{pg} / \mathrm{mL}$ dibandingkan dengan median TPO kontrol $57 \mathrm{pg} / \mathrm{mL}$ dengan peningkatan yang lebih tinggi terjadi pada sepsis berat dan syok septik (461 dan $522 \mathrm{pg} / \mathrm{mL}$ ). ${ }^{30}$ Peneliti lain melaporkan konsentrasi TPO plasma meningkat pada neonatus dengan infeksi bakteri dibanding dengan kontrol pada usia yang sama. Sebuah penelitian pada neonatus usia 1-10 hari menunjukkan nilai median TPO 1704 pg/mL pada sepsis dibandingkan dengan penyakit non infeksi $659 \mathrm{pg} / \mathrm{mL} .{ }^{12}$ Kadar TPO meningkat secara bermakna pada hari ke 4-5, dan tidak didapatkan perbedaan yang bermakna antara jumlah trombosit, TPO dan progenitor megakariosit pada bayi prematur. ${ }^{31}$
Penelitian kami merupakan penelitian pertama yang membandingkan antara TPO dengan profil hematologi. Berdasarkan hasil analisis dengan ROC didapatkan area under curve (AUC) 51,3\% dan nilai cut off TPO $259 \mathrm{pg} / \mathrm{mL}$, dengan nilai sensitivitas 77,4\%, spesifisitas 24,4\%, NDP 63,6\%, dan NDN 76,5\%.

Hasil uji Z TPO dibandingkan dengan jumlah Leukosit dan jumlah trombosit memperlihatkan TPO lebih sensitif, tetapi spesifisitas TPO lebih rendah. Tidak dijumpai perbedaan sensitivitas TPO dibanding IT rasio, tetapi spesifisitas IT rasio lebih tinggi dibanding TPO. Dengan demikian, kadar TPO pada penelitian kami tidak lebih baik dibanding beberapa profil hematologi dalam membantu diagnosis SNAD.

Disimpulkan bahwa sensitivitas dan spesifisitas TPO tidak lebih tinggi dibandingkan dengan profil hematologi dalam mendiagnosis SNAD. Keterbatasan dari penelitian kami adalah metode dilakukan secara potong lintang sehingga belum dapat melihat peran TPO secara menyeluruh.

\section{Daftar pustaka}

1. Aminullah A, Gatot D, Kosim S, Rohsiswatmo R, Indarso F, Dharma R, dkk. Penatalaksanaan Sepsis Neonatorum. Jakarta: Departemen Kesehatan Republik Indonesia;2007:1-85.

2. Makkar M, Gupta C, Pathak R, Garg S, Mahajan NC. Performance evaluation of hematologic scoring system in early diagnosis of neonatal sepsis. J Clin Neo 2013:25-9.

3. Thaver D, Zaidi AK. Burden of neonatal infections in developing countries. Pediatr Infect Dis J 2009;28:3-9.

4. Juniatiningsih A, Asril Aminullah, Agus Firmansyah. Profil mikroorganisme penyebab sepsis neonatorum di Departemen Ilmu Kesehatan Anak Rumah Sakit Cipto Mangunkusumo Jakarta. Sari Pediatri 2008;10:60-5.

5. Wilar R, Antolis Y, Tatura SN, Gunawan S. Jumlah trombosit dan mean platelet volume sebagai faktor prognosis pada sepsis neonatorum. Sari Pediatri 2010;12:53-7.

6. Aminullah A. Sepsis pada bayi baru lahir. Dalam: Kosim MS, Yunanto A, Dewi R, Sarosa GI, Usman A, penyunting. Buku Ajar Neonatologi. Edisi 1. Jakarta :Badan Penerbit IDAI; 2008.h.170-87

7. Triphati S, Malik GK. Neonatal sepsis: past, present and future; a review article. Int J Med 2010;5:45-54.

8. Polin RA, Committee on fetus and newborn. Management of neonates with suspected or proven early-onset bacterial sepsis. Pediatrics 2012;129:1005-16.

9. Newman TB, Puopolo KM, Wi S, Draper D, Escobar GJ. 
Interpreting complete blood counts soon after birth in newborns at risk for sepsis. Pediatrics 2010;126:903-9.

10. Kayange N, Kamugisha E, Mwizamholya DL, Jeremiah S, Mshana SE. Predictors of positive blood culture and deaths among neonates with suspected neonatal sepsis in tertiary hospital, Mwanza-Tanzania. BMC Pediatrics 2010;10:1-9.

11. Brown RE, Rimza LM, Pastos K, Young L, Saxonhouse MA, Bailey M, dkk. Effects of sepsis on neonatal thrombopoiesis. Pediatr Res 2008; 64: 399-404.

12. Colarizi P, Fiorucci P, Caradonna A, Ficuccili F, Mancuso M, Papoff P. Circulating thrombopoietin levels in neonates with infection. Acta Paediatr 1999;88:332-7.

13. Oygür N, Tunga M, Mumcu Y, Yeşilipek A, Güra A, Coşkun M, dkk. Thrombopoietin levels of thrombocytopenic term and preterm newborns with infection. Am J Perinatol 2001;18:279-86.

14. Eissa DS, El-Farrash RA. New insights into thrombopoiesis in neonatal sepsis. Platelets 2013;24:122-8.

15. Oetomo MT. Risk factors of neonatal sepsis: a preliminary studyin Dr. Soetomo Hospital. Indonesian J Trop Infect Dis 2010;1:23-6.

16. Setyawati, Ariningrum D, Intansari US, Lutfia E. Penampilan diagnostic parameter-parameter hematologi untuk diagnosis sepsis neonatal. Berkala Ilmu Kedokteran 2006;106:251-5.

17. Putra PJ. Insiden dan faktor-faktor yang berhubungan dengan sepsis neonatal di RSUP Sanglah Denpasar. Sari Pediatri 2012;14:205-10.

18. Hornik CP, Benjamin DK, Becker KC, Li J, Clark RH, Wolkowiez C, dkk. Use of the complete blood cell count in early-onset neonatal sepsis. Pediatr Infect Dis J 2012;31: 799-802.

19. Fischbach FT, Dunning MB. Overview of basic blood hematology and coagulation tests. In: A manual laboratory and diagnostic tests. Edisi ke-8. Philadelphia: Lippincott William\& Wilkins; 2009.h.70-1154.
20. Urlichs FSC. Neutrophil function in preterm and term infants. Neorev 2004;5:417-30.

21. Marodi L. Innate cellular immune responses in newborn. Clin Immunol 2006;118:137-44.

22. Frey B, Horton SB, Duke T, Shann F. The immature to total neutrophil ratio (IT Ratio) is a sensitive indicator of sepsis neonatorum. Schweiz Med Wochenschr 2000;130:1572-5.

23. Holzhauer S, Zieger B. Diagnosis and management of neonatal thrombocytopenia. Semin Fetal Neonatal Med 2011;16:305-10.

24. Roberts I, Murray NA. Neonatal thrombocytopenia: causes and management. Arch Dis Child Fetal Neonatal 2003;88:359-64.

25. Aird WC. The hematologic system as a marker of organ dysfunction in sepsis. Mayo Clin Proc 2003;78:869-81.

26. Levi M, Lowenberg EC, Thrombocytopenia in critically ill patients. Semin Thromb Hemost 2008;34:417-24.

27. Dame C. Developmental biology of thrombopoietin in the human fetus and neonate. Acta Pædiatr 2002;Suppl 438:5465.

28. Folman CC, Linthorst GE, van Maourik J, van Wiligen G, de Jonge E, Levi M, dkk. Platelet releases thrombopoietin (TPO) upon activation; another regulatory loop in thrombocytopoiesis. hry loop in thrombocytopoiesis. Tromb Haemos 2000;3:923-30.

29. Tonbary YA, Haggar MA, Salama O, Kheir MA, El-Alfy A, Hafez M. Platelet count and serum thrombopoietin level as predictors for morbidity and/or mortality in thrombocytopenic neonates. Hematology 2012;17:341-5.

30. Zakynthinos SG, Papanikolaou S, Theodoridis T, Zakynthinos EG, Christopoulou-Kokkinou V, dkk. Sepsis severity is the major determinant of circulating thrombopoietin levels in septic patients. Crit Care Med 2004;32:1004-10.

31. Sola-Visner M, Sallmon H, Brown R. New insights into the mechanisms of non-immune thrombocytopenia in neonates. Semin Perinatol 2009;33:43-51. 